Estuarine, Coastal and Shelf Science

February 2016, Volume 169, Pages 216-226

http://dx.doi.org/10.1016/j.ecss.2015.12.010

http://archimer.ifremer.fr/doc/00301/41212/

(c) 2015 Elsevier Ltd. All rights reserved.

\title{
Poor oxic conditions in a large estuary reduce connectivity from marine to freshwater habitats of a diadromous fish
}

\author{
Tétard Stéphane ${ }^{1,{ }^{*}}$, Feunteun Eric ${ }^{1}$, Bultel Elise ${ }^{1}$, Gadais Romain ${ }^{1,2}$, Bégout Marie-Laure ${ }^{3}$, \\ Trancart Thomas ${ }^{1}$, Lasne Emilien ${ }^{1}$
}

${ }^{1}$ UMR BOREA Muséum National d'Histoire Naturelle - CRESCO, 38, rue du Port Blanc 35800 DINARD, France

${ }^{2}$ UMR ESE INRA/Agrocampus Ouest, 65 rue de Saint-Brieuc, 35042 RENNES cedex, France

${ }^{3}$ Ifremer, Laboratoire Ressources Halieutiques, Place Gaby Coll, 17137 L'HOUMEAU, France

* Corresponding author : Stéphane Tétard, Tel.: +3313087 78 11. ;

email address : stephane.tetard@edf.fr

\begin{abstract}
:
Connectivity in aquatic systems is often related to abundance and permeability of physical barriers, such as dams, which delay or impede movements of biota with important consequences for aquatic biodiversity. Water quality may, however, also control connectivity between essential habitats. In macrotidal estuaries, Estuarine Turbidity Maxima (ETM) have a strong impact on water quality because of the low oxygen concentration occurring as a response to the related high bacterial and low photosynthetic activities. In this study, we assess Allis shad estuarine spawning migration in 2011 and 2012 in the Loire River (France) where the ETM occurs at spring and summer. Using an acoustic telemetry array, we show that trans-estuarine migration is inhibited during hypoxic episodes in the middle part of the estuary. Shad tends to stay in downstream areas, and even at sea, where oxygen conditions are more suitable. Trans-estuarine migration occurs hastily during neap tide when the ETM decreases, both in terms of spatial extent and intensity, inducing a shift in a set of covariates including dissolved oxygen, which increases, and suspended matter, which decreases. In the context of climate warming, ETM are expected to increase with probable adverse implications for shad migration success and doubtless other diadromous populations.
\end{abstract}

Keywords : connectivity, hypoxic conditions, acoustic telemetry, estuarine migration, Allis shad 


\section{Introduction}

Disruption of connectivity along rivers is known to be a major cause of freshwater aquatic biodiversity loss, especially for fish (Lucas and Baras 2001; Pringle et al. 2000), and among them diadromous species which decline throughout the world (Limburg and Waldman 2009). At an individual level, connectivity alteration may prevent fish from reaching essential habitats, such as spawning habitats, and accomplishing their life cycle (Lucas et al. 2009). At a population level, it may impede (re-) colonization of habitats, reduce population dynamics and jeopardize viability (Morita and Yamamoto 2002). Connectivity is usually considered from a physical point of view and its alteration is evaluated, for instance, by counting the number and characterizing the permeability of physical obstacles such as dams or other infrastructures (Bourne et al. 2011; Cote et al. 2009; Fullerton et al. 2010; Hall et al. 2011; Laffaille et al. 2009). Therefore, most management plans target these obvious obstacles to improve fish movements and restore populations: fish passage may be settled (Prato et al. 2011) or dams may be removed (Hart et al. 2002), for instance. Conversely, the absence of such barriers is generally assumed to allow fish to freely move between habitats and connectivity can be considered as good. Other factors may however control fish habitats connectivity. Among them, physico-chemical conditions, which are much more variable and difficult to assess, can also limit or even impede fish movements (Buysse et al. 2008; Lucas and Baras 2001; Maes et al. 2008). Low dissolved oxygen level, high temperature or suspended matter level may act as real barriers to fish migration but their impact is rarely investigated.

Macrotidal estuaries of large rivers often develop a Estuarine Turbidity Maximum (ETM). The conjunction of tide and river flow results in the resuspension of fine particles. Moreover, two phenomena occur with increasing salinity: organic matter, resulting from the death of aquatic organisms experiencing fatal osmotic stress, increases and dissolved matter flocculates. Yet the high turbidity reduces the photosynthetic activity and the increase of bacterial activity resulting from this amount of dissolved matter available leads to high oxygen consumption. Therefore, ETM may be associated with hypoxic or even anoxic conditions, especially under high temperatures and low river flows (Abril et al. 1999; Talke et al. 2009). Although ETM are natural phenomena, anthropogenic activities can exacerbate its development in terms of intensity, duration, frequency and spatial extent. For instance, channelization or deepening of estuaries for navigation may severely impact mudflat 
functionality (i.e., reduced sediment trapping) and can also extend the ETM (Kerner 2007; Talke et al. 2009). In the context of global change, water temperature increases and concurrent declines in discharge will favour the development of ETM and hypoxic, even anoxic, episodes (Lanoux et al. 2013). Although this phenomenon can be advantageous for larval and juvenile fish feeding and survival due to higher prey concentrations (Islam and Tanaka 2006), some fish populations could be, and are probably already, negatively impacted by it (Marchand 1993; Thouvenin et al. 1994). Therefore, this phenomenon deserves particular attention especially since the effect of restoring riverine physical continuity in the upstream parts of catchments would be unfruitful if migration is disturbed in the estuarine bottleneck. Indeed, it has been shown that, the further downstream the barriers to migration occur, the stronger the consequences on diadromous fish are (Cote et al. 2009; Lucas et al. 2009; Rolls 2011).

Whereas they have severely declined, and some species have already disappeared in various large and medium Western European systems (Limburg and Waldman 2009), the Loire River (France) is considered as one of the last bastions for diadromous fish. Indeed, most of them are still present e.g., Atlantic salmon Salmo salar (Linnaeus 1758), European eels Anguilla anguilla (L. 1758), sea lamprey Petromyzon marinus (L. 1758), river lamprey Lampetra fluviatilis (L. 1758), Allis shad Alosa alosa (L. 1758) and Twaite shad Alosa fallax (Lacépède, 1803). It is suspected that this diversity results from a reasonably good connectivity level along the main axes i.e., the Loire and Allier rivers (Lasne and Laffaille 2008). Nonetheless, various factors such as pollution and obstructions in tributaries contributed to population declines (Steinbach 2001). In addition to these upstream pressures, it is likely that an ETM developing in the Loire Estuary and causing episodic hypoxic or even anoxic conditions could be problematic for diadromous fish (Etcheber et al. 2007; Marchand 1993; Thouvenin et al. 1994) or other amphihaline, such as grey mullet (Sauriau et al. 1994), and may be the main factor affecting population within the catchment (Steinbach 2001).

In this study, the impacts of the ETM and associated hypoxic conditions on a diadromous fish, the Allis shad, is addressed. Dissolved oxygen concentrations (DO) $<3 \mathrm{mg} \cdot \mathrm{I}^{-1}$ are known to be stressful for migrating spawners in other alosine species (Chittenden 1973; Maes et al. 2008) and thus, may be stressful for Allis shad too. Unfortunately, such low concentrations have been observed in the Loire River estuary at spring during the migratory period of shads (Thouvenin et al. 1994). In order to evaluate Allis shad behaviour facing such supposedly 
stressful conditions and the impact on the onset and patterns of the spawning migration, we used an acoustic telemetry array deployed in the Loire River estuary in 2011 and 2012. Migratory patterns were investigated in medium to late migratory periods when hypoxic and anoxic episodes were likely to occur. We tested the hypothesis that migratory behaviour is disrupted during hypoxic or anoxic conditions, which could therefore delay estuarine migration with probable consequences on spawning success.

\section{Materials and Methods}

\section{Study area}

The Loire River catchment is the largest one in France with a drainage area of $117000 \mathrm{~km}^{2}$. On average, the discharge at the catchment mouth is about $850 \mathrm{~m}^{3} . \mathrm{s}^{-1}$ with significant interand intra-annual fluctuations. Indeed, the Loire River is subject to very intense flash floods from autumn to spring and to severe drought from spring to autumn. The Loire itself is $1012 \mathrm{~km}$ long and has relatively good connectivity for fish in a large downstream part $(<500$ $\mathrm{km}$ from the tidal limit). The main tributary, the Allier River, is almost free of impassable barriers and might be colonized by a well-known relict Atlantic salmon population (Perrier et al. 2011). The Vienne River has been restored (Maison Rouge dam dismantled in 1999) and recolonization by diadromous species is expected. Conversely, most of the other tributaries have been largely regulated by dams whose impact on diadromous fish distribution is severe, for instance in the Maine catchment (Laffaille et al. 2009; Lasne and Laffaille 2008). In terms of water quality, the Loire River has very high nitrates and ammonia levels due to farming activities i.e., livestock and fertilizers (Moatar and Meybeck 2005). Conversely, the impact of industrial activity on water quality is relatively low (Moatar and Meybeck 2007). The fluvial part of the Loire River itself (e.g., upstream of the estuary) seems to be rarely or locally affected by hypoxic conditions (Moatar et al. 1999). Considering the limit of tidal influence as the upstream boundary at Varades, the Loire River estuary is about $80 \mathrm{~km}$ (Fig. 1). Its width varies from 4000 next to the outlet to $200 \mathrm{~m}$ upstream. It has been largely modified for navigation purposes, and more precisely, it has been deepened. As a result, the influence of tide has moved upstream and mudflats do not play their role of sediment trapping anymore, contributing to the reinforcement of the ETM.

In the Loire River, Allis shad spawn 550-750 km from the sea (Boisneau et al. 1990). After 3-6 months in freshwaters, juveniles leave the river to the sea, where growth lasts for 4 to 5 
years. Adults penetrate the estuaries from April to May/early June (Baglinière and Elie 2000; Rochard 2001). Most individuals are semelparous but a fraction (<10\%) may reproduce twice (Baglinière and Elie 2000). Although very little information is available on Loire's population status, it is suspected to decline (Bach et al. 2015) and, in the Gironde system (the other large and close river historically supporting large populations), the population collapsed in the recent decades (Rougier et al. 2012).

\section{Environmental data}

Since 2007, a number of physico-chemical phenomena are being monitored in the estuary by GIP Loire Estuaire (www.loire-estuaire.org): maximum turbidity zone, hypoxia and salinity. The ETM corresponds to the area where the concentration of suspended matter exceeds 1 g. I $^{-1}$ and is mainly located in the lower part of the estuary (Etcheber et al. 2007). In 2011 it moved up in the upper estuary (GIP Loire Estuaire, comm. pers.). ETM may be associated with areas characterised by a dissolved oxygen concentration lower than $5 \mathrm{mg} . \mathrm{l}^{-1}$ and even down to $1 \mathrm{mg} . \mathrm{I}^{-1}$ (Thouvenin et al. 1994) (see Abril et al. (1999) for details on the underlying processes). Environmental data were provided by GIP Loire-Estuaire (www.loire-estuaire.org) and came from Paimboeuf (dissolved oxygen, measured every 10 minutes), Cordemais (salinity and suspended matter, hourly obtained) and Le Pellerin (temperature, measured every 10 minutes) (Fig. 1). Using different stations was necessary to provide complete data series for each variable since some stations had long periods of non-available data due to sensor problems. Small time shifts due to tide influence between these near sites were negligible as daily mean of these data have been used. Measurements were automatically made every 10 to 60 minutes, depending on the stations. Mean daily flow was available at the DREAL measurement station of Montjean, $30 \mathrm{~km}$ upstream of Oudon (Fig. 1). Tide coefficients were obtained from the Port Autonome de Saint Nazaire.

\section{Telemetry array}

In 2011, a first set of 17 hydrophones VR2W (Vemco $\left.{ }^{\circledR}\right)$ anchored on navigation buoys was deployed from the upper part of the Loire Estuary (Oudon) to its lower end (Paimboeuf) (Fig. 1). In 2012, 17 additional receivers were deployed and the array covered about $100 \mathrm{~km}$ of the lower river and estuary. These hydrophones were deployed as lines of 2 to 6 units to optimize detection along the estuary forming 11 acoustic lines (Fig. 1). 


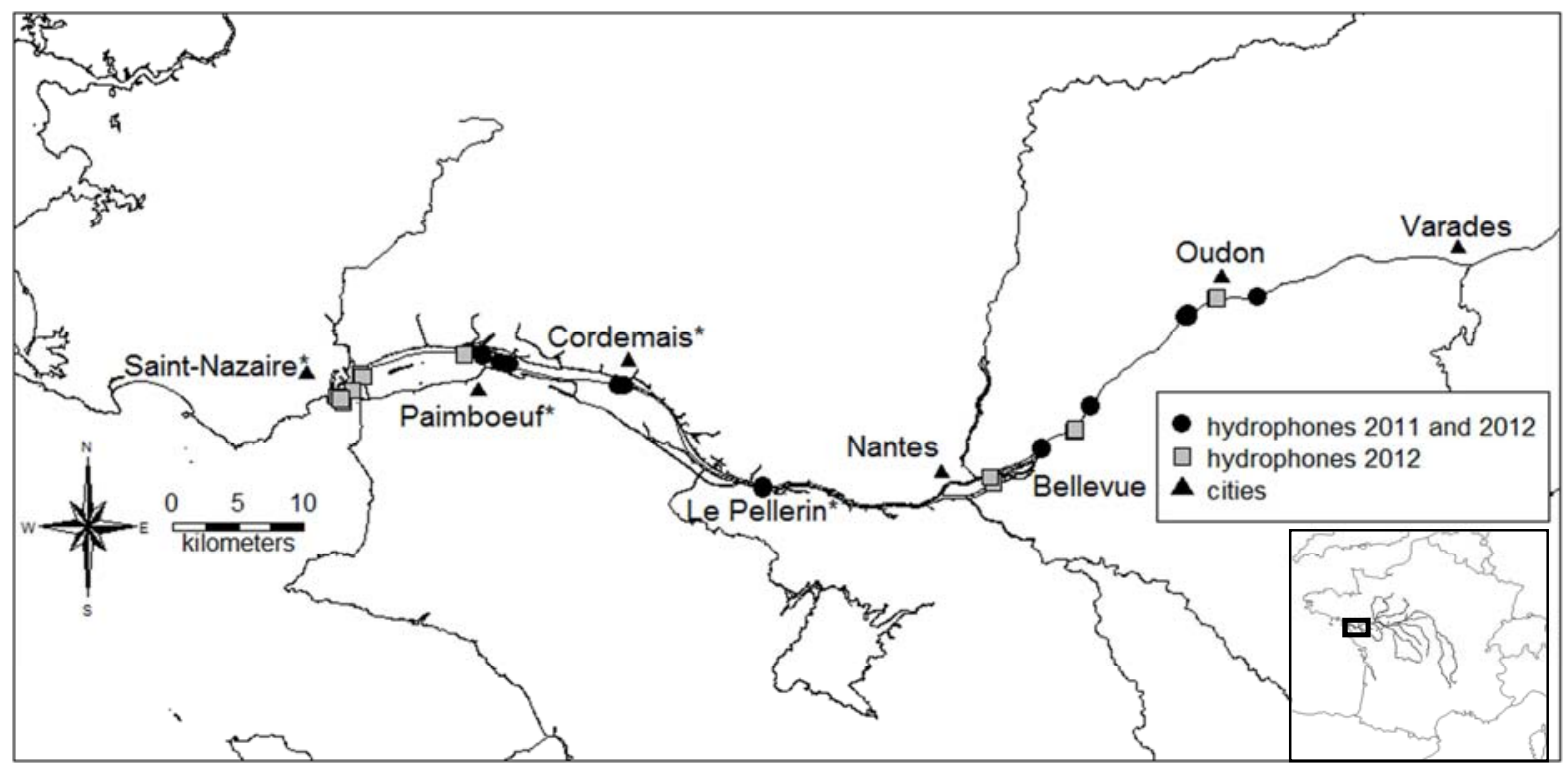

Figure 1: Loire estuary and the acoustic array. Asterisks shows sites with environmental measurement stations

\section{Fish catching and tagging}

Sixteen fishing campaigns with a professional fisherman (using a small aluminium boat) took place between Paimboeuf and Cordemais, from March to June, both in 2011 and 2012 (Fig. 1). Eight tagging sessions occurred each year at different tidal periods for about 3 hours mostly as the tide rose up (i.e., two hours before high tide to one hour after)(Table 1). Allis shad were captured using a trammel net (mesh size $=60 \mathrm{~mm}$, length $=200$ or $320 \mathrm{~m}$, depth $=$ $4 \mathrm{~m}$ ) operated from the boat and regularly pulled in order to limit the duration of entanglement undergone by the fish. Shads were stored on board in a 500 I tank supplied with the river water and additional oxygen with an air diffuser. Acoustic tagging occurred as soon as possible in a 100 I tub also supplied with river water and an air diffuser. Fish were kept in water during tagging: their body was gently held with the mouth out of the water and the acoustic tags were carefully inserted through the mouth into the stomach following Acolas et al. (2004) protocol. No anaesthesia was performed on board the fishing vessel and it also enabled a faster return of the shad in their natural environment. Stomach ingested acoustic tags were either MP13 or MP9L acoustic transmitters (size $3.1 \mathrm{~cm}$ long, $1.3 \mathrm{~cm}$ diameter for MP13 and $2.8 \mathrm{~cm}$ long, $0.9 \mathrm{~cm}$ diameter for MP9L, Thelma ${ }^{\circledR}$ Trondheim, Norway) and weighed respectively, $11.4 \mathrm{~g}$ in air (7.3 g in water) and $5.2 \mathrm{~g}$ in air (3.3 g in water). Transmitters were programmed to emit a coded acoustic signal (at a frequency of 69 $\mathrm{kHz}$ ), individually recognizable, either every 10 to 30 seconds or 20 to 60 seconds. 
Transmitters' weights in air always represented less than $2 \%$ of the fish body weight as recommended in Winter (1996). While the fish were still held in the water tub, external spaghetti tags (Floy Tag \& Mfg. Inc., Seattle, Washington USA) with individual identification numbers were inserted with a tagging gun at the base of the dorsal fin to inform fishermen of the shads' special status, encourage their release, and allow the identification of the individuals caught. Fork length and body weight were measured just before release while holding a wet mop on the shad snout to prevent injury and calm it down.

In total, 51 Allis shad were tagged and released in 2011 and 27 in 2012. The mean body weight (W) of the shad was $1780 \pm 544 \mathrm{~g}$ in 2011 (from 1182 to $3760 \mathrm{~g}, \mathrm{n}=35$ ) and $2308 \pm$ $582 \mathrm{~g}$ in 2012 (from 1200 to $3100 \mathrm{~g}, \mathrm{n}=26$ ). The mean fork length was $503 \pm 37 \mathrm{~mm}$ in 2011 (from 421 to $613 \mathrm{~mm}, \mathrm{n}=51$ ) and $531 \pm 38 \mathrm{~mm}$ in 2012 (from 445 to $590 \mathrm{~mm}, \mathrm{n}=27$ ). The Relative Weight $\left(W_{R}\right)$ was considered as a proxy of the shad individual health status (Blackwell et al. 2000). $W_{R}$ was calculated as $W_{R}=\left(W / W_{S}\right) \times 100$, where $W=$ actual fish weight and $W_{S}$ a standard weight for fish of the same length. The mean $W_{R}$ was $99.67 \pm 1.87$ in 2011 (from 92.48 to 104.39, $n=43$ ) and 100.52 2.92 in 2012 (from 93.12 to 104.79, n=27). Although the equation of $W_{S}$ requires total length, fork lengths were used since total length measure is difficult on shads because of their tail shape and the resulting difference in the $\mathrm{W}_{\mathrm{S}}$ calculation is conservative. 
Table 1: Allis shad tagging sessions in 2011 and 2012. (HT = High Tide, LT = Low Tide, Nb = number of Alosa alosa tagged and released).

\begin{tabular}{ccc}
\hline Date & Tide & Nb \\
\hline $28 / 04 / 2011$ & HT & 8 \\
$29 / 04 / 2011$ & LT & 6 \\
& HT & 9 \\
$11 / 05 / 2011$ & HT & 13 \\
& LT & 3 \\
$12 / 05 / 2011$ & HT & 9 \\
$19 / 05 / 2011$ & HT & 1 \\
$08 / 06 / 2011$ & HT & 2 \\
\hline $29 / 03 / 2012$ & HT & 1 \\
& LT & 6 \\
& HT & 10 \\
$30 / 03 / 2012$ & HT & 4 \\
$06 / 04 / 2012$ & HT & 1 \\
$27 / 04 / 2012$ & HT & 1 \\
$12 / 05 / 2012$ & HT & 0 \\
$13 / 05 / 2012$ & HT & 0 \\
$15 / 05 / 2012$ & HT & 0 \\
$16 / 05 / 2012$ & LT & 1 \\
& HT & 3 \\
$13 / 06 / 2012$ & HT & 0 \\
$14 / 06 / 2012$ & HT & 0 \\
\hline
\end{tabular}

\section{Data analysis}

\section{Typology of migratory behaviours}

As a first approach, shad migration was qualitatively analyzed by comparing the individual migration profiles and classifying them in a typology based on pattern similarity. This typology revealed that, for most individuals, the estuarine migration was composed of two steps: first, a residence time in the downstream part of the estuary and second, an active and rapid migration upstream. The first step often displayed bouts of adjacent upstream and downstream movements. Such short term downstream movements were not necessarily an adverse reaction to tagging and may represent the normal diversity of movements (Frank et al. 2009). Consequently, they cannot be a priori excluded from the dataset. Therefore, for each individual, two metrics were measured: the residency time in the downstream part of the estuary before migrating throughout the estuary, and the speed of migration throughout the estuary. The residency time was calculated using the release time (in the downstream estuary) and the time of last detection in this area (at Cordemais, near the release point, Fig. 
1). The speed of migration was calculated using the time of last detection in the downstream part (in Cordemais, Fig. 1) and the last detection in the upstream part of the estuary (in Oudon, $54 \mathrm{~km}$ from release point, Fig. 1) and the corresponding distance. In case of nondetection in Cordemais, the detections in Paimboeuf (the closest site in the downstream estuary) were used. Relationships between these migratory descriptors and shad individual traits were examined using analysis of variance (ANOVA with 3 factors: fork length, body weight and $\left.W_{R}\right)$.

\section{Trans-estuarine migration triggering}

As a second approach, we intended to correlate migration profiles with environmental data to identify migration triggers. A preliminary graphical analysis of data suggested that migratory activity could be related to tidal coefficient (tabular system ranging from 20 to 120 that depicts the magnitude of an expected tide), suspended matter and dissolved oxygen (Fig. 2). Therefore, we aimed to detect if any components of the migratory signal (global daily upstream migration variables, defined hereafter) could be linked to the components of observed environmental data signals.

\subsection{Mathematical approach}

Identifying rhythmicity in biological time series is usually performed by two statistical methods: autocorrelations or methods based on the maximum of entropy (Dowse 2007; Dowse and Ringo 1989). In this study, Maximum Entropy Spectral Analysis (MESA) (Burg $1967 ; 1968)$ was chosen, because it has been shown to have a much better resolution in time series analysis than other methods (Ables 1974; Kay and Marple 1981). Resolution, specifically, is the ability of the technique to separate input signals into discrete peaks in the spectrum. Moreover, MESA does not normally produce spurious peaks in the spectrum corresponding to "harmonics" of the true period (Dowse and Ringo 1989). For example, if a signal contains a period of 12.4 hours, autocorrelation function can show a correlation at 12.4 hours and at 24.8 hours. Conversely, MESA will only extract the 12.4 hours period. MESA is based on a Fourier transform whereby reliable information on period, phase and signal robustness can be extracted from biological rhythm data (Dowse 2007). However, MESA requires continuous data series with available data at each time lag whereas our shad detection dataset was composed of erratic detection data. 


\subsection{Creating a global daily upstream migration variable for shads}

Since individual detection data were temporally uneven, a regulation method was applied ( $R$ function 'regul') to obtain a daily frequency in the individual distance analyses. Data from both years were considered, but only during the time period where shads showed migratory behaviour i.e., from $29^{\text {th }}$ April to $25^{\text {th }}$ June in 2011 and from $30^{\text {th }}$ March to $15^{\text {th }}$ May in 2012. The regulated data series were created for each shad with detected migratory behaviour by optimizing the number of temporal matches between the raw series and the daily series (changing the initial value of the series and the lag) and a linear interpolation was used in between. For a given date, individual daily distances travelled were calculated and summed over all individuals and weighted by the number of shads present in the estuary and likely to migrate (shads which showed no sign of activity were removed from this analysis because it was impossible to determine if the fish was alive). This number was assessed by counting the number of shads having been detected and having showed a movement in the estuary before reaching Oudon (Fig. 1.). Indeed, the shads which were still not detected at a given date but later in the migratory period were regarded as 'available shads'. This average daily distance was used as our movement variable (global daily upstream migration variable) to highlight even the minor migration episodes undertook by only few individuals. For shads showing upstream migration with several attempts, all data were considered in the analysis.

\subsection{Signal conditioning}

MESA implied a preliminary signal conditioning to obtain a stationary signal: high frequency noise and non-linear trends where removed using a pass band Butterworth filter (8-12-35-55 days) (Bolliet et al. 2007; Trancart et al. 2012). This filter was also applied on all environmental variables. MESA is a very powerful test, able to highlight several cycles in the same time series. However, having daily time series means that periodicities less than two days will not be detected. Indeed, Nyquist-Shannon theorem states that the sampling frequency has to be at least twice the highest frequency contained in the signal (Nyquist 2002). In the case of our study, there were more than two days between migrating events (i.e. implying several fishes), so this methodological constraint was not considered to be an issue.

2.4. Searching for periodicities in time series 
In order to understand which - if any - environmental factors triggered the migration, the global daily upstream migration variable would have to be juxtaposed with the daily means of dissolved oxygen (DO; mg..$\left.^{-1}\right)$, salinity $\left(S ; g . I^{-1}\right)$, suspended matter $\left(S M\right.$; g. $\left.I^{-1}\right)$, temperature (T; ${ }^{\circ} \mathrm{C}$ ), mean daily flow (DF; $\mathrm{m}^{3} \cdot \mathrm{s}^{-1}$ ) and mean daily tide (dimensionless). Potential periodicities in the global daily upstream migration variable could reflect the periodicities of the environmental factors in the estuary and would therefore allow the assessment of certain factors' roles in the migration sparking.

All the statistical analyses were made with the R-Cran project free software (http://www.rproject.org/; packages signal and pastecs). Differences were considered statistically significant at $p<0.05$.

\section{Results}

\section{Acoustic detections and migration patterns}

Out of the 51 Allis shad tagged in 2011, 44 (86 \%) were detected at least once and 29 fish (66\%) displayed a trans-estuarine migratory behaviour (we considered 'migrant', shads which moved from the lower estuary up to, at least, Oudon, Fig 1). Out of the 27 Allis shads tagged in 2012, 18 (66.7 \%) were detected at least once, and only 6 shads (33\%) have shown a transestuarine migratory behaviour. Considering the shad traits (fork length, body weight and $W_{R}$ ), no significant differences were found between migrant shads and non-migrant shads (ANOVA, $\mathrm{p}>0.05$ ). Two shads were caught by fishermen: one in the lower estuary, close to the release point (Paimboeuf), 13 days after tagging and the other one $110 \mathrm{~km}$ upstream of the last acoustic line, 20 days after tagging.

Based on the global migration profiles, in both years, the onset of trans-estuarine migration tended to occur when tide coefficients were low, which corresponded to times where daily dissolved oxygen and suspended matter rates were respectively high and low (Fig. 2). Other factors such as salinity, temperature and river flow were not graphically linked to migration events. A MESA was applied on all of them to provide a quantitative assessment of these preliminary observations. 

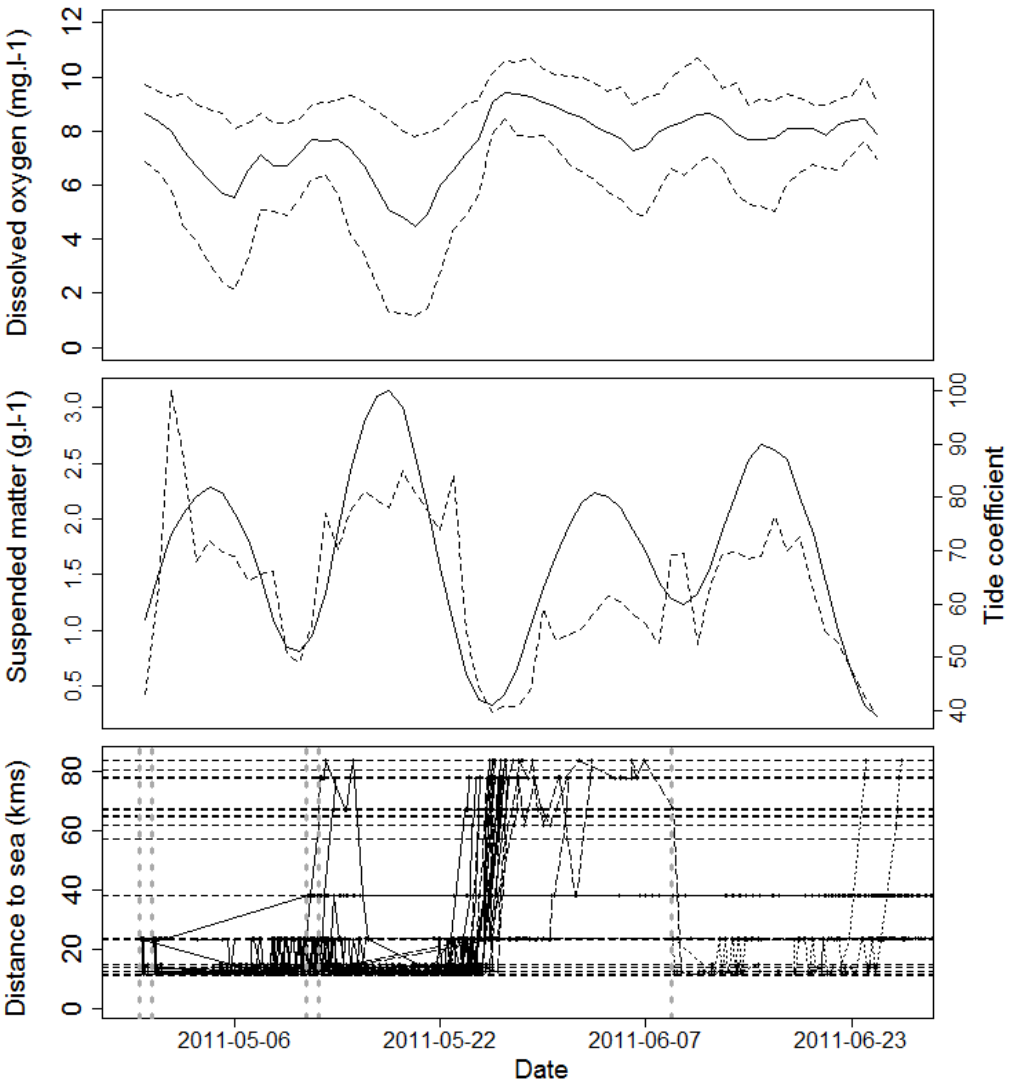

a)
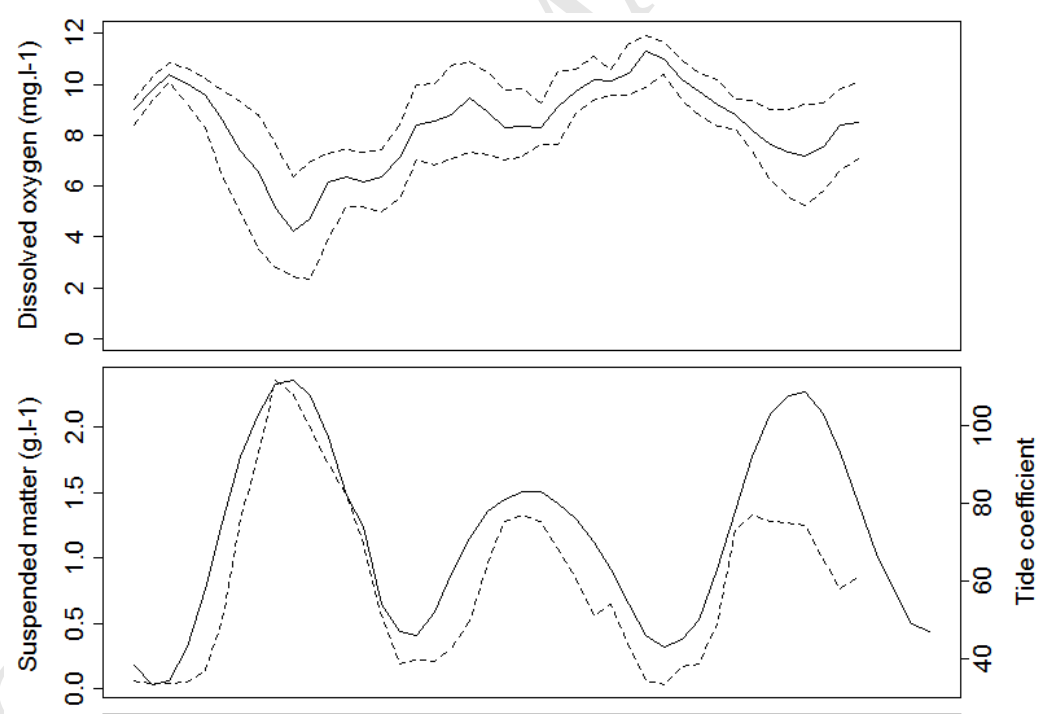

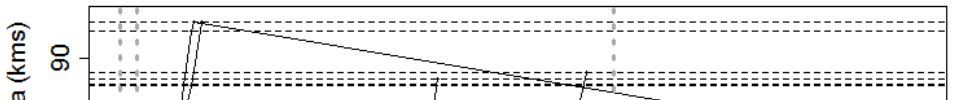

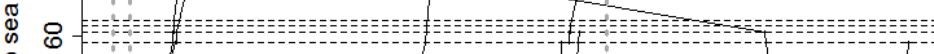

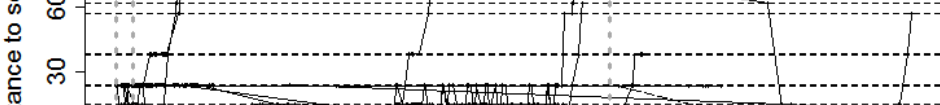

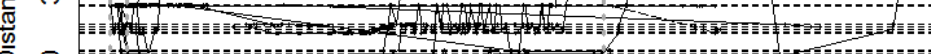

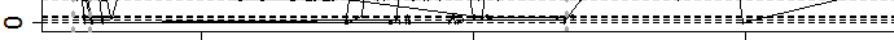

b)

Date

Figure 2: From top to bottom for a) 2011 and b) 2012: daily dissolved oxygen, with min and max indicated by dashed lines (from 4.49 to $9.41 \mathrm{mg} \cdot \mathrm{L}^{-1}$ in 2011 and from 4.22 to $11.28 \mathrm{mg} . \mathrm{L}^{-}$ ${ }^{1}$ in 2012)) ; daily suspended matter (dashed line, from 0.23 to 3.15 g. $\mathrm{L}^{-1}$ in 2011 and from 
0.03 to 2.36 g. $\mathrm{L}^{-1}$ in 2012) and daily mean tide coefficient (full line, from 39 to 100 in 2011 and from 33 to 112 in 2012); and shad movement patterns (full line indicate individual trajectory, vertical dashed lines indicate days of fish tagging, horizontal dashed lines indicate positions of hydrophones arrays)

\section{Individual migration patterns}

A typology of individual movement patterns was performed and showed strong interindividual contrasts: 6 patterns displayed different movement histories (patterns $A, B, C, D, E$, F) while three detection patterns $(G, H, I)$ showed 'abnormal' trajectories (related to methodological problems such as tag loss or catching/tagging induced mortality). One of the migratory patterns $(A)$ was very common whereas others were rarely observed (Table 2 ).

Pattern A: This pattern is characterized by a 'waiting' phase with small oscillation movements in the downstream part of the estuary followed by a quick departure towards the upstream part of the estuary. A number of shads (almost $75 \%$ ) of this group showed a lack of detections period in the first days after the release. The additional hydrophones installed in Saint-Nazaire (kilometric reference) in 2012 showed that some individuals went back to the sea for a variable period of time (up to 15 days in this case; Fig. 3).

Pattern B: This behaviour was observed on two shads in 2011. These shads migrated to upstream stretches of the estuary, together with other tagged individuals, but then returned back downstream and migrated again upstream during another collective migration episode following a subsequent tagging session.

Pattern C: This pattern is very similar to B but related to one fish only, which did not migrate upstream again after going back downstream. Different hypothesis can be formulated: either it went back to sea or it died (fishing or predation...). A tag dysfunction or regurgitation could also be possible explanations.

Pattern D: This pattern applied to one fish, which, after showing a similar oscillating downstream profile, migrated upstream and oscillated in upstream areas of the estuary.

Pattern E: This behaviour was observed on seven shads, which did not seem to adopt oscillation movements downstream but returned back to sea and then migrated upstream without any observed oscillations.

Pattern F: The profile related to one shad, which quickly migrated upstream with a short waiting phase (39 hours) downstream. 
Pattern G: This pattern was only observed in 2012 on 3 shads which were detected just after their release, close to the release site, then detected downstream but never after. The possible explanations are similar to those listed in pattern $C$ (back to sea, death, tag dysfunction or regurgitation).

Pattern H: This pattern was very surprising, both from a methodological and a biological point of view. The only shad concerned was detected several times downstream after the release and then heard upstream ( $77 \mathrm{~km}$ from the sea) 6 months later, without any other detection in between. Several clues suggest that, in fact, this shad did not migrate. Indeed, both a winter migration and a migration event without any detection in the intermediate parts of the estuary seem very unlikely, especially since the period without any detection is very long. The fish probably returned to sea without attempting an upstream migration and/or died. The single detection upstream could be explained by technical dysfunctions in the acoustic system.

Pattern I: The shads included in this pattern were only detected near the release site for a few hours to several weeks. We could not determinate whether the fish was still alive but immobile or if the detection was due to the tag regurgitation or death of the fish near a listening hydrophone. 
Pattern A

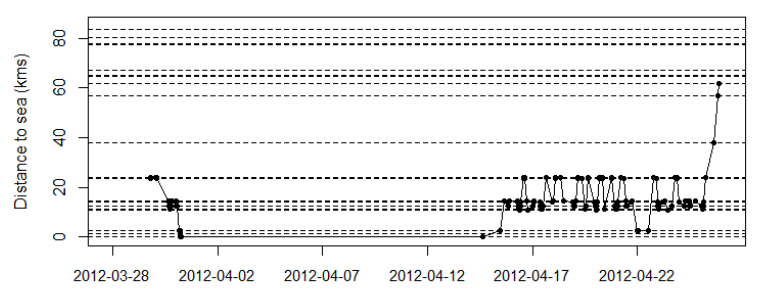

Date

Pattern B

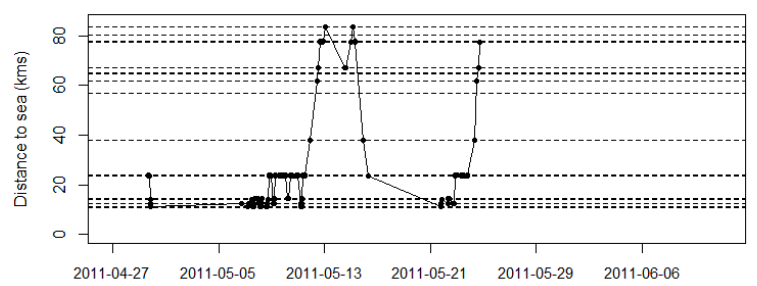

Date

Pattern E

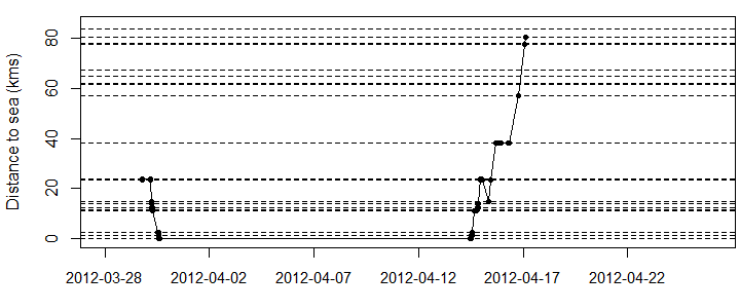

Date

Pattern F

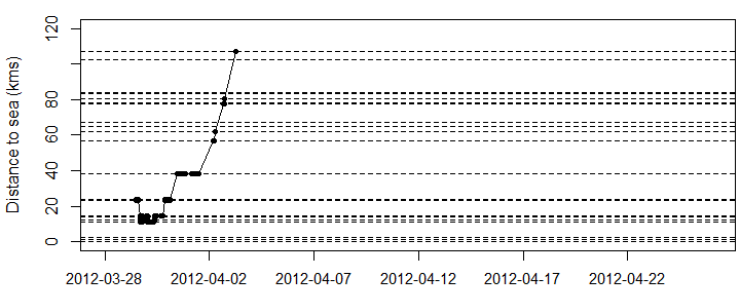

Date

Pattern I

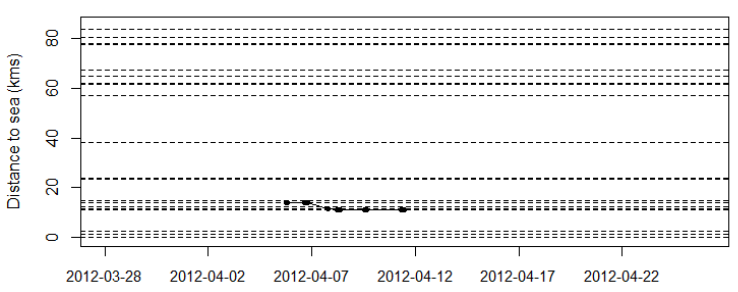

Date
Pattern C

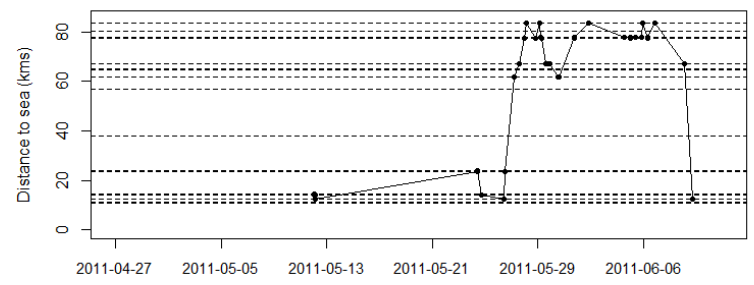

Date

Pattern D

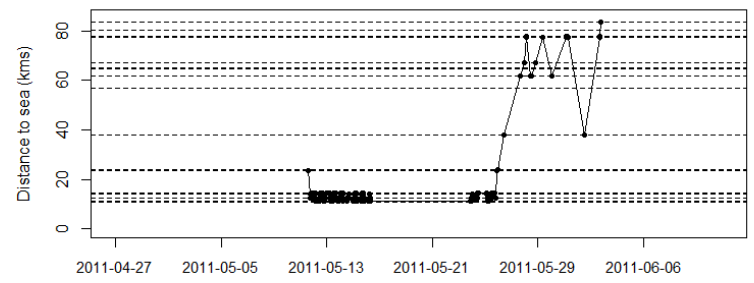

Date

Pattern G

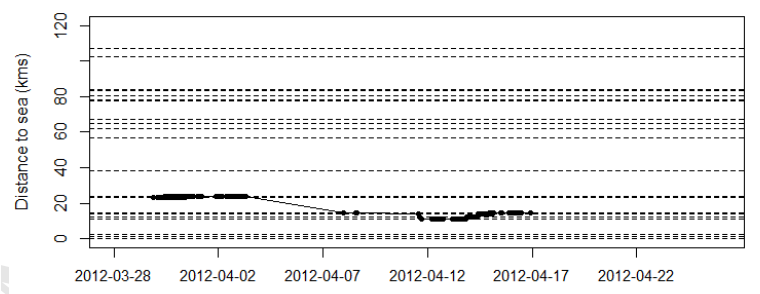

Date

Pattern H

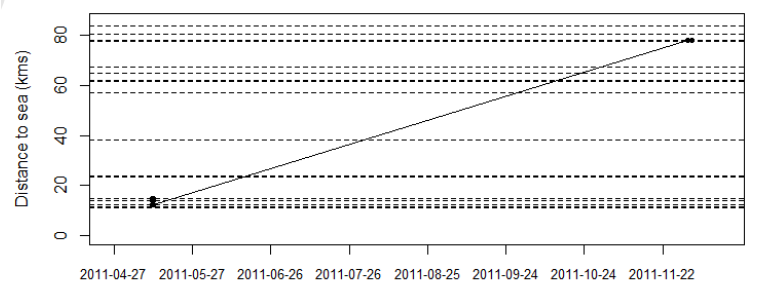

Date

Figure 3: Migration patterns observed in 2011 and 2012. Arrays of hydrophones are represented by dashed lines (---) 
Table 2: Number and frequency of occurrence of the different migration patterns observed in 2011 and 2012.

\begin{tabular}{cccccc}
\hline & \multicolumn{2}{c}{2011} & & 2012 & Total \\
\hline Pattern & Number & Frequency & Number & Frequency & Frequency \\
\hline A & 21 & $47.73 \%$ & 2 & $11.11 \%$ & $37.10 \%$ \\
\hline B & 1 & $2.27 \%$ & 1 & $5.55 \%$ & $3.23 \%$ \\
\hline C & 1 & $2.27 \%$ & 0 & $0 \%$ & $1.61 \%$ \\
\hline D & 1 & $2.27 \%$ & 0 & $0 \%$ & $1.61 \%$ \\
\hline E & 5 & $11.36 \%$ & 2 & $11.11 \%$ & $11.29 \%$ \\
\hline F & 0 & $0 \%$ & 1 & $5.55 \%$ & $1.61 \%$ \\
\hline G & 0 & $0 \%$ & 3 & $16.67 \%$ & $4.84 \%$ \\
\hline H & 1 & $2.27 \%$ & 0 & $0 \%$ & $1.61 \%$ \\
\hline I & 14 & $31.82 \%$ & 9 & $50 \%$ & $37.10 \%$ \\
\hline
\end{tabular}

\section{Residence time downstream}

Mean residence time in the downstream part of the estuary (i.e., downstream Cordemais) before migration was 18.5 days ( $\pm 7.28 \mathrm{SD}$, range 1.8-27.1). Fork length, bodyweight, and $W_{R}$ of shads had no influence on mean residence time in the downstream part of the estuary (ANOVA, $p>0.05$ ).

\section{Migration speeds}

The migration behaviour of 30 individuals was available for this analysis, including 26 from 2011 and 4 from 2012. Considering the small data set in 2012 as well as the similarities between the migratory patterns between the two years (Fig. 3), data from both years were pooled for migration speed calculations. Mean speed was $51.60 \mathrm{~km} . \mathrm{d}^{-1}$ (i.e., $0.60 \mathrm{~m} . \mathrm{s}^{-1}$ ) ranging from $21.13 \mathrm{~km} . \mathrm{d}^{-1}$ (i.e., $0.24 \mathrm{~m} . \mathrm{s}^{-1}$ ) to $91.43 \mathrm{~km} . \mathrm{d}^{-1}$ (i.e., $1.06 \mathrm{~m} . \mathrm{s}^{-1}$ ) (SD $=17.38 \mathrm{~km} . \mathrm{j}^{-1}$ / $0.20 \mathrm{~m} . \mathrm{s}^{-1}$ ), meaning that it took the fastest shad about 1 day to travel from Cordemais to Oudon (Fig. 1). No relationship was found between fork length and $W_{R}$ and migration speeds (ANOVA, $\mathrm{p}>0.05$ ). However, a relationship between fish body weight and migration speed was found: heavier fish migrated faster (ANOVA, $p<0.05$ ). 
5. Spectral density and rhythms

Three rhythms in the global daily upstream migration variable were found in 2011: 15.13, 18.98 and 26.22 days (Fig. 4). The most important one in terms of spectral density was the first one, i.e., 15.13 days (d). Very similar rhythms (Fig. 5) were found for oxygen (25.36 d), river flow (18.17 and $25.46 \mathrm{~d}$ ), suspended matter (14.83 d), salinity (26.67 d), and tide coefficient (15.74 d) (Fig. 5).

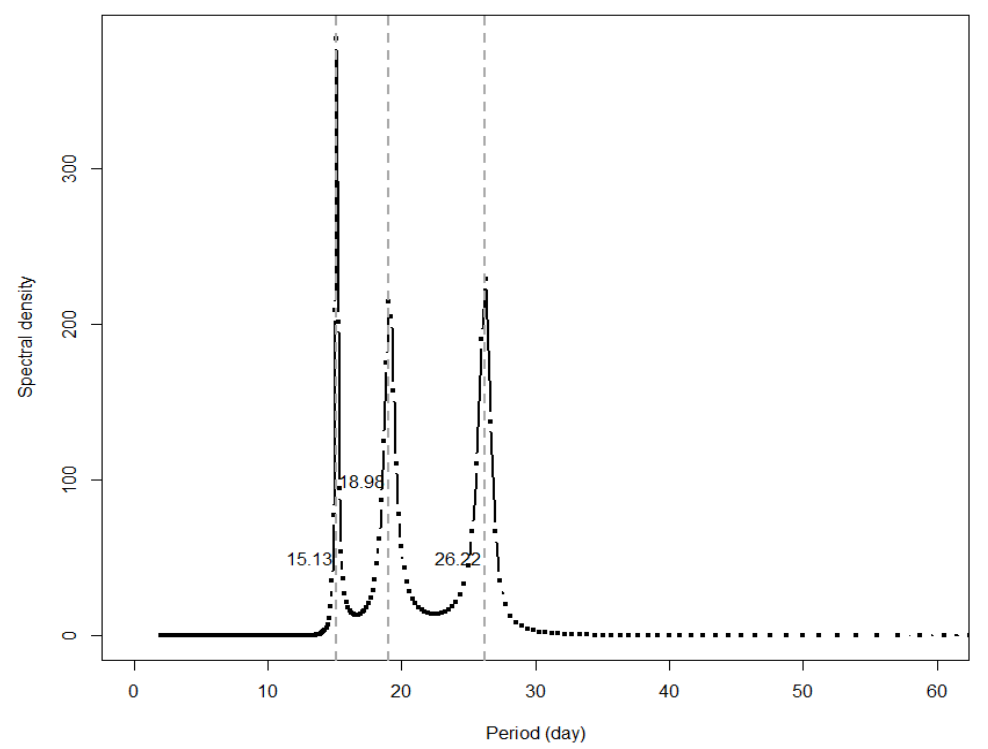

Figure 4: Spectral density for the distance travelled in 2011. The three main rhythms are highlighted in grey (15.13, 18.98 and 26.22 days). 

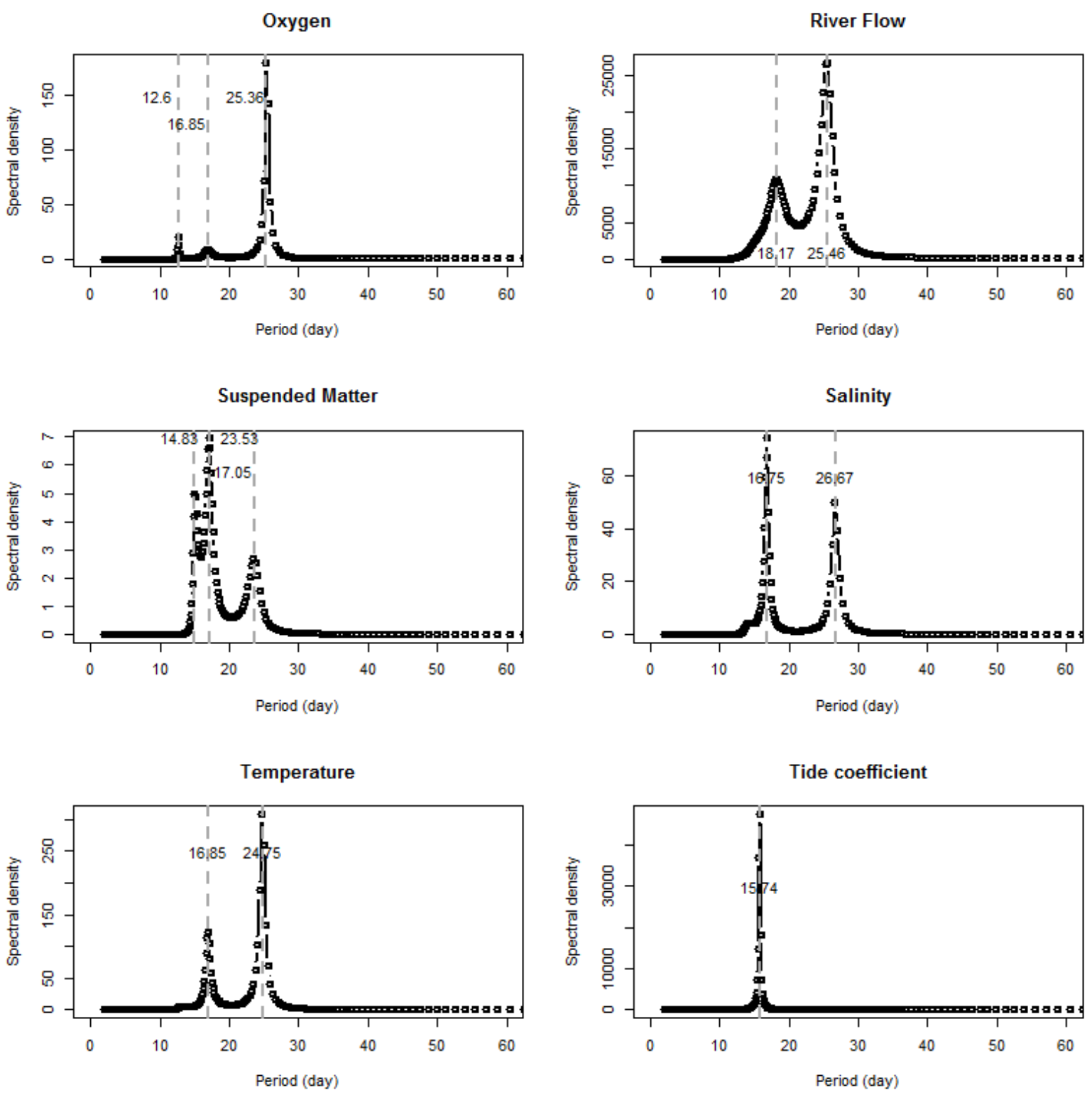

Figure 5: Spectral density on each environmental variable considered in 2011. Major rhythms are highlighted by a dashed grey line.

These rhythms are close to the lunar revolution period (29.53 d) and half revolution period (14.7 d). The rhythms found in tide coefficient (15.74 d) and in suspended matters (14.83 d) are also very close to the lunar half period. Although a slight difference exists (approximately $26 \mathrm{~d}$ versus $29 \mathrm{~d}$ ), the rhythms found in oxygen ( $25.36 \mathrm{~d}$ ), river flow ( $25.46 \mathrm{~d}$ ) and salinity (26.67 d) are close to this revolution period. 
These results are consistent with the observations made on the global daily upstream migration

(Fig. 2): maximal distance travelled, including active trans-estuarine migration, occurred at neap tides when oxygen was high, salinity was lower than during spring tides and suspended matter was low.

Results from 2012 were roughly similar to those from 2011. Global daily upstream migration showed three periodicities: $13.57,16.62$ and 24.35 days which can be found in oxygen (13.6 d), suspended matter (12.52 and $15.68 \mathrm{~d}$ ), salinity (23.77 d), temperature (15.68 d) and tide coefficient rhythms (14.86 d). Periodicities found in oxygen (26.25 d), river flow (9.35 and $26.35 \mathrm{~d}$ ) and temperature (25.99 d) were different. Although these results come from a small sample, the periodicities found were consistent with the 2011 results, emphasizing the match between distance travelled and oxygen, suspended matter, salinity and tide coefficient patterns.

\section{Discussion}

Migration through estuaries is a key event in diadromous fish life-cycles (Lucas and Baras 2001). In Europe, physico-chemical conditions in large estuaries are likely to be stressful for migratory fishes, due to the development of ETM associated with hypoxic conditions, and may prevent fish movement. In our study, environmental conditions during Allis shad migration period were strongly fluctuating in the Loire River estuary mainly according to tide coefficients. Specifically, dissolved oxygen concentration could drop below $3 \mathrm{mg} . \mathrm{l}^{-1}$ which is known to be stressful for migrating spawners or juveniles in related species of shads (Chittenden 1973; Maes et al. 2008). Indeed, this can greatly influence the success with which the adults migrate upstream (Chittenden 1974) and the juveniles move seaward in the summer and fall (Chittenden, 1969). As raised by Chittenden (1974), the resurgence of the population of American shad in 1907 in the Delaware River after years of decline may have been permitted by one of the greatest flood ever recorded in October 1903 which may have enhanced the water quality when the juveniles were migrating seaward.

The acoustic telemetry array enabled to analyse the movement patterns of a significant set of individuals. As raised by Dodson et al. (1972), it is important to disentangle the contribution of natural behaviour and the capture and tagging impacts which could disturb migratory behaviour. Based on data involving a relatively similar design, these authors assumed little impact of tagging on fish behaviour. In our study, if catching and handling had 
disturbed shad migratory behaviour, altered behaviour was mainly expected in the following hours whereas our study covers a much longer period. Moreover, short term downstream movements associated with upstream movements were almost systematically observed, whether just after the release or after a long time. Although it can be surprising for an anadromous fish, it may represent the normal diversity of movements and they cannot be a priori excluded from the dataset (Frank et al. 2009). Rare patterns aside (i.e., individual patterns related to unknown methodological problems such as tag loss, catching/tagging induced mortality or technical dysfunctions in the acoustic system), we do not have evidence that fish behaviour was strongly modified although this cannot be totally ruled out. Our acoustic telemetry array permitted the observation of a range of variability in Allis shad individual behaviours in both a qualitative and quantitative manner.

After capture and tagging, most individuals remained in the lower estuary with relatively small longitudinal meandering movements and possibly some movements back at sea for variable periods of time. Such oscillating movements were also observed on five shads in a set of seven tagged individuals of Alosa sapidissima in the Connecticut River estuary for times ranging from 24 to 53 hours and were assumed to result from relatively passive behaviour with tidal currents close to the salt wedge (Dodson et al. 1972). These authors attributed this behaviour to physiological adaptation to freshwaters before starting riverine migration. However, in our study, shad could exhibit such meandering patterns for much longer (18.5 days on average). Although a phase of adaptation to lower salinity is likely in our case as well, it is possible that fish spent time waiting for a favourable window of migration. Indeed, conditions in the most downstream part of the estuary and at sea could be buffered in terms of flow and physicochemical conditions and would therefore be less stressful for shad than upstream conditions. In fact, the ETM mainly develops between Paimboeuf and Le Pellerin (Fig. 1) with both amplitude and intensity positively correlated to tidal coefficient and negatively correlated to river discharge (GIP Loire-Estuaire 2014). After this 'waiting phase', trans-estuarine migration did not occur randomly but mainly during neap tides. Tidal amplitude is thus a main driver of environmental conditions in the Loire estuary as it determines the occurrence of the ETM and the concentration of both suspended matter and oxygen (Abril et al. 1999; Doxaran et al. 2009; Lanoux et al. 2013). These two observations (i.e., a 'waiting phase' in the downstream zone and conversely no residency behaviour within the medium or upper estuary) are in accordance with the assumption that the estuary 
upstream of Paimboeuf-Cordemais, corresponding to the ETM zone, is hostile most of the time. In the Loire River, oxygen level fluctuations are probably strong enough to control fish movement and trans-estuarine migration. In 2011, which was a relatively warm year, river flow had a positive impact on migration. It is likely that flow increase contributes to reduce ETM through freshwater input (Brenon and Le Hir 1999) and consequently, favours migration.

The most successful individuals had a similar pattern, showing active and direct migration upstream. Our acoustic array was not extended enough to show any breaks in the migration process of the individuals, if there were any, once the active migration was engaged. Considering the high average migration speed (mean speed during active spawning run was $51.60 \mathrm{~km} . \mathrm{j}^{-1}$ ranging from 21.13 to $91.43 \mathrm{~km} . \mathrm{j}^{-1}$ ), it is likely that shads had little to no stops. These values are relatively high compared to those estimated by other authors: 17 to 23 $\mathrm{km} . \mathrm{j}^{-1}$ in the Gironde Estuary (Rochard 2001), $21 \mathrm{~km} . \mathrm{j}^{-1}$ in the Loire Estuary (MennessonBoisneau and Boisneau 1990) or $20.5 \mathrm{~km} . \mathrm{j}^{-1}$ in the freshwater Loire River (Steinbach et al. 1986). Estimated speeds in Alosa sapidissima ranged between 8.5 and $80.4 \mathrm{~km}^{-1} \mathrm{j}^{-1}$ in the Connecticut River (Katz 1986). After this run, some rare individuals that had successfully crossed the estuary moved back, i.e., seaward, possibly with another successful transestuarine migration. Such behaviour, also observed in Alosa sapidissima (Dodson et al. 1972), do not seem to be adaptive as it involves increased energy expenditure as well as increased mortality risk and was rare in our data set. No indication of the causes of such behaviour is available yet. Morphometric variables had no effect on migratory patterns and only fish body weight positively influenced migration speed. Bernatchez and Dodson (1987) showed, in a set of fish including a few shad species, that there was a negative relationship between energetic cost of migration and fish body weight. These authors also assumed that environmental constraints, irrespective of the migration distance, impede to minimize energy expenditure. Bigger fishes could then afford to spend more energy by swimming faster to leave the hostile ETM area. No relationship between migration speed and body condition index $\left(W_{R}\right)$ was found in our study. This possibly results from the poor discriminating power of the index we used, also possibly from the sample size and a confounding sex effect.

ETM in large estuaries will probably increase in the coming years as a response to predicted increasing temperature, flow modification and urbanization (Lanoux et al. 2013). In the Loire River, it has already increased in the last century especially due to habitat degradation i.e., 
estuary channelization and deepening. It is also likely that ETM will occur earlier in spring in relation to increased temperature and lower hydrological level of rivers or increasing human populations (Lanoux et al. 2013). Under such conditions, shad populations could be imperilled because of reduced connectivity to spawning ground. Using a modelling approach, Castro-Santos and Letcher (2010) showed that delayed arrival at spawning grounds due to habitat fragmentation in Alosa sapidissima could have dramatic implication on reproductive success by increasing the energetic demand devoted to migration. Therefore, a reduction of migratory opportunities through low oxygen levels reducing connectivity in the Loire River could also lead to reduced reproductive success and contribute to the decline of shad population. As a response to the predicted increased and earlier development of ETM, we would expect a phenological shift for shads. More precisely, migration should occur earlier to match more favourable migratory conditions, although there might be some unknown costs associated to such a shift. Most Allis shads are semelparous (Baglinière and Elie 2000), thus selection against late migrants (and therefore most likely exposed to ETM) might be strong and possibly rapid, provided that migratory tactics are variable enough within population. Our results also question the fate of juvenile shads during their seaward migration, as the first individuals migrate as soon as August (Lochet et al. 2009) when the ETM is still well developed. But the potential threats also exist for lampreys and Atlantic salmon spawners during spring and summer. In the Loire River catchment, as well as in most other large catchments, management efforts mainly focus on freshwater habitats to restore longitudinal (dams) and lateral (wetlands) connectivity. Little is done in estuaries to compensate the habitat loss and degradation of the water quality (including ETM), while restoration of tidal and flood plain habitats of the estuary could reduce the overall ETM by trapping suspended sediments and increasing freshwater inputs from lateral backwaters. In turn such management actions are likely to improve connectivity between upstream and downstream habitats for migrating fish. However, in the context of climate change, all these actions could be counterbalanced by estuarine connectivity loss in the coming years and this issue deserves further research.

\section{Acknowledgments}

We thank the professional fishermen for their contribution to the sampling sessions. We thank the GIP Loire Estuaire, the Port Autonome de Saint-Nazaire and the Direction Régionale de l'Environnement, de l'Aménagement et du Logement des Pays de la Loire 
(DREAL) for the environmental data they provided. We thank the Saint-Nazaire Phares et Balises subdivision as well as La Chapelle Basse-Mer DDTM team for their help during the acoustic device deployment phase. The acoustic arrays were funded by the French Ministry of Environment. 


\section{References}

Ables JG. 1974. Maximum entropy spectral analysis. Astronomy and Astrophysics Supplement 15:383393.

Abril G, Etcheber H, Le Hir P, Bassoullet P, Boutier B, Frankignoulle M. 1999. Oxic/anoxic oscillations and organic carbon mineralization in an estuarine maximum turbidity zone (The Gironde, France). Limnology and Oceanography 44(5):1304-1315.

Acolas ML, Bégout Anras ML, Veron V, Jourdan H, Sabatie MR, Bagliniere JL. 2004. An assessment of the upstream migration and reproductive behaviour of allis shad (Alosa alosa L.) using acoustic tracking. Ices Journal of Marine Science 61(8):1291-1304.

Bach JM, Parouty T, Léon C, Senecal A, Portafaix P, Cloastre T, Defours A, Baisez A. 2015. Recueil de données biologiques 2014 sur les poissons migrateurs du bassin Loire. Rapport d'activité. Association LOGRAMI. p. 191.

Baglinière JL, Elie P. 2000. Les aloses (Alosa alosa et Alosa fallax spp.) : Ecobiologie et variabilité des populations. Paris: CEMAGREF-INRA. p. 275.

Blackwell BG, Brown ML, Willis DW. 2000. Relative Weight (Wr) Status and Current Use in Fisheries Assessment and Management. Reviews in Fisheries Science 8(1):1-44.

Boisneau P, Mennesson-boisneau C, Bagliniere JL. 1990. Description of a spawning ground and reproductive behaviour of the Allis shad (Alosa alosa L.) in the upper river Loire. Bulletin Francais De La Peche Et De La Pisciculture(316):15-23.

Bolliet V, Lambert P, Rives J, Bardonnet A. 2007. Rhythmic swimming activity in Anguilla anguilla glass eels: Synchronisation to water current reversal under laboratory conditions. Journal of Experimental Marine Biology and Ecology 344(1):54-66.

Bourne CM, Kehler DG, Wiersma YF, Cote D. 2011. Barriers to fish passage and barriers to fish passage assessments: the impact of assessment methods and assumptions on barrier identification and quantification of watershed connectivity. Aquatic Ecology 45(3):389-403.

Brenon I, Le Hir P. 1999. Modelling the Turbidity Maximum in the Seine Estuary (France): Identification of Formation Processes. Estuarine, Coastal and Shelf Science 49(4):525-544.

Burg JP. 1967 Maximum Entropy Spectral Analysis. 37th Meeting of the Society of Exploration Geophysicists; Oklahoma City, Oklahoma.

Burg JP. 1968. A new analysis technique for time series data. NATO advanced study Institute on Signal Processing with Emphasis on Underwater Acoustics; Enschede, Netherlands.

Buysse D, Coeck J, Maes J. 2008. Potential re-establishment of diadromous fish species in the River Scheldt (Belgium). Hydrobiologia 602:155-159.

Castro-Santos T, Letcher BH. 2010. Modeling migratory energetics of Connecticut River American shad (Alosa sapidissima): implications for the conservation of an iteroparous anadromous fish. Canadian Journal of Fisheries and Aquatic Sciences 67(5):806-830.

Chittenden M, Jr. 1973. Effects of handling on oxygen requirements of American Shad (Alosa sapidissima). Journal of the Fisheries Research Board of Canada 30(1):105-110.

Chittenden M, E. 1974. Trends in the abundance of American shad, Alosa sapidissima, in the Delaware River Basin. Chesapeake Science, 15(2), 96-103.

Chittenden M, E. 1969. Life history and ecology of the American shad, Alosa sapidissima, in the Delaware River. Ph.D. dissertation, Rutgers University, New Brunswick, NJ.

Cote D, Kehler DG, Bourne C, Wiersma YF. 2009. A new measure of longitudinal connectivity for stream networks. Landscape Ecology 24(1):101-113.

Dodson JJ, Leggett WC, Jones RA. 1972. The Behavior of Adult American Shad (Alosa sapidissima) During Migration from Salt to Fresh Water as Observed by Ultrasonic Tracking Techniques. Journal of the Fisheries Research Board of Canada 29(10):1445-1449.

Dowse H. 2007. Statistical Analysis of Biological Rhythm Data. In: Rosato E, editor. Circadian Rhythms. Humana Press. p. 29-45.

Dowse HB, Ringo JM. 1989. The search for hidden periodicities in biological time series revisited. Journal of Theoretical Biology 139(4):487-515. 
Doxaran D, Froidefond J-M, Castaing P, Babin M. 2009. Dynamics of the turbidity maximum zone in a macrotidal estuary (the Gironde, France): Observations from field and MODIS satellite data. Estuarine Coastal and Shelf Science 81(3):321-332.

Etcheber H, Taillez A, Abril G, Garnier J, Servais P, Moatar F, Commarieu MV. 2007. Particulate organic carbon in the estuarine turbidity maxima of the Gironde, Loire and Seine estuaries: origin and lability. Hydrobiologia 588:245-259.

Frank H. J., Mather M. E., Smith J. M., Muth R. M., Finn J. T., \& McCormick S. D. 2009. What is "fallback"?: metrics needed to assess telemetry tag effects on anadromous fish behavior. Hydrobiologia, 635(1), 237-249.

Fullerton AH, Burnett KM, Steel EA, Flitcroft RL, Pess GR, Feist BE, Torgersen CE, Miller DJ, Sanderson BL. 2010. Hydrological connectivity for riverine fish: measurement challenges and research opportunities. Freshwater Biology 55(11):2215-2237.

GIP Loire-Estuaire. 2014. La dynamique du bouchon vaseux. Cahiers Indicateurs. GIP Loire Estuaire.

Hall CJ, Jordaan A, Frisk MG. 2011. The historic influence of dams on diadromous fish habitat with a focus on river herring and hydrologic longitudinal connectivity. Landscape Ecology 26(1):95107.

Hart DD, Johnson TE, Bushaw-Newton KL, Horwitz RJ, Bednarek AT, Charles DF, Kreeger DA, Velinsky DJ. 2002. Dam removal: Challenges and opportunities for ecological research and river restoration. Bioscience 52(8):669-681.

Islam M. S, Tanaka M, 2006. Spatial variability in nursery functions along a temperate estuarine gradient: role of detrital versus algal trophic pathways. Canadian Journal of Fisheries and Aquatic Sciences, 63(8), 1848-1864.

Katz HM. 1986. Migrational swimming speeds of the American shad, Alosa sapidissima, in the Connecticut River, Massachusetts, U.S.A. Journal of Fish Biology 29:189-197.

Kay SM, Marple SL, Jr. 1981. Spectrum analysis\&\#8212;A modern perspective. Proceedings of the IEEE 69(11):1380-1419.

Kerner M. 2007. Effects of deepening the Elbe Estuary on sediment regime and water quality. Estuarine Coastal and Shelf Science 75(4).

Laffaille $P$, Lasne $E$, Baisez A. 2009. Effects of improving longitudinal connectivity on colonisation and distribution of European eel in the Loire catchment, France. Ecology of Freshwater Fish 18(4):610-619.

Lanoux A, Etcheber H, Schmidt S, Sottolichio A, Chabaud G, Richard M, Abril G. 2013. Factors contributing to hypoxia in a highly turbid, macrotidal estuary (the Gironde, France). Environmental Science-Processes \& Impacts 15(3):585-595.

Lasne E, Laffaille P. 2008. Analysis of distribution patterns of yellow European eels in the Loire catchment using logistic models based on presence-absence of different size-classes. Ecology of Freshwater Fish 17(1):30-37.

Limburg KE, Waldman JR. 2009. Dramatic Declines in North Atlantic Diadromous Fishes. Bioscience 59(11):955-965.

Lochet A, Boutry S, Rochard E. 2009. Estuarine phase during seaward migration for allis shad Alosa alosa and twaite shad Alosa fallax future spawners. Ecology of Freshwater Fish 18(2):323335.

Lucas M, Baras E. 2001. Migration of Freshwater Fishes. Oxford, United Kingdom: Blackwell Science. p. 440.

Lucas MC, Bubb DH, Jang M-H, Ha K, Masters JEG. 2009. Availability of and access to critical habitats in regulated rivers: effects of low-head barriers on threatened lampreys. Freshwater Biology 54:621-634.

Maes J, Stevens M, Breine J. 2008. Poor water quality constrains the distribution and movements of twaite shad Alosa fallax (Lacepede, 1803) in the watershed of river Scheldt. Hydrobiologia 602:129-143. 
Marchand J. 1993. The influence of seasonal salinity and turbidity maximum variations on the nursery function of the Loire estuary (France). Netherland Journal of Aquatic Ecology 27(2-4):427436.

Mennesson-Boisneau C, Boisneau P. 1990. Recherches sur les aloses (Alosa sp.) dans le bassin de la Loire. University of Paris 7 and Rennes 1. p. 139.

Moatar F, Meybeck M. 2005. Compared performances of different algorithms for estimating annual nutrient loads discharged by the eutrophic River Loire. Hydrological Processes 19(2):429-444.

Moatar F, Meybeck M. 2007. Riverine fluxes of pollutants: Towards predictions of uncertainties by flux duration indicators. Comptes Rendus Geoscience 339(6):367-382.

Moatar F, Poirel A, Obled C. 1999. Analysis of data series measurements of dissolved oxygen and pH in the Loire River at Dampierre nuclear power plant: 1. Temporal patterns of dissolved oxygen and $\mathrm{pH}$ in relation to hydrometeorological data. Hydroécologie Appliquée 11:127151.

Morita K, Yamamoto S. 2002. Effects of habitat fragmentation by damming on the persistence of stream-dwelling charr populations. Conservation Biology 16(5):1318-1323.

Nyquist H. 2002. Certain topics in telegraph transmission theory. Proceedings of the IEEE 90(2):280305.

Perrier C, Guyomard R, Bagliniere JL, Evanno G. 2011. Determinants of hierarchical genetic structure in Atlantic salmon populations: environmental factors vs. anthropogenic influences. Molecular Ecology 20(20):4231-4245.

Prato EP, Comoglio C, Calles O. 2011. A simple management tool for planning the restoration of river longitudinal connectivity at watershed level: priority indices for fish passes. Journal of Applied Ichthyology 27:73-79.

Pringle CM, Freeman MC, Freeman BJ. 2000. Regional effects of hydrologic alterations on riverine macrobiota in the New World: Tropical-temperate comparisons. Bioscience 50(9):807-823.

Rochard E. 2001. Anadromous estuarine migration of adult allis shad Alosa alosa, shape of the phenomenon and influence of the tidal cycle. Bulletin Francais De La Peche Et De La Pisciculture(362-63):853-867.

Rolls RJ. 2011. The role of life-history and location of barriers to migration in the spatial distribution and conservation of fish assemblages in a coastal river system. Biological Conservation 144(1):339-349.

Rougier T, Lambert P, Drouineau H, Girardin M, Castelnaud G, Carry L, Aprahamian M, Rivot E, Rochard E. 2012. Collapse of allis shad, Alosa alosa, in the Gironde system (southwest France): environmental change, fishing mortality, or Allee effect? Ices Journal of Marine Science 69(10).

Sauriau PG, Robin JP, Marchand J. 1994. Effects of the excessive organic enrichment of the Loire Estuary on the downstream migratory patterns of the amphihaline grey mullet (Liza ramada)(Pisces: Mugilidae). In: Dyer KR, Orth RJ, editors. Changes in Fluxes in Estuaries: Implications from Science to Management. ECSA 22/ERF Symposium; Helstedsvej, Denmark: Olsen and Olsen. p. 349-356.

Steinbach P. 2001. Situation and restoration of amphihalin migratory fishes in the Loire basin. Bulletin Francais De La Peche Et De La Pisciculture(357-60):263-276.

Steinbach P, Gueneau P, Autuoro A, Broussard D. 1986. Radio-pistage de grandes aloses adultes en Loire. Bull. Fr. Pêche Piscic.(302):106-117.

Talke SA, de Swart HE, de Jonge VN. 2009. An Idealized Model and Systematic Process Study of Oxygen Depletion in Highly Turbid Estuaries. Estuaries and Coasts 32(4).

Thouvenin B, Le Hir P, Romana LA. 1994. Dissolved oxygen model in the Loire Estuary. In: Dyer K, Orth $R$, editors. Changes in fluxes in estuaries: implications from science to management. Fredensborg, Denmark: Olsen and Olsen. p. 169-178.

Trancart T, Lambert P, Rochard E, Daverat F, Coustillas J, Roqueplo C. 2012. Alternative flood tide transport tactics in catadromous species: Anguilla anguilla, Liza ramada and Platichthys flesus. Estuarine, Coastal and Shelf Science 99(0):191-198. 
Winter JD. 1996. Underwater biotelemetry. In: L. A. Nielsen aDLJ, editor. Fisheries techniques. Bethesda, MD.: American fisheries Society. p. 555 - 590. 